\title{
THE ACTUAL IMPACT OF WASTE-TO-ENERGY PLANT EMISSIONS ON AIR QUALITY: A CASE STUDY FROM NORTHERN ITALY
}

\author{
Giovanni Lonati ${ }^{1, *}$, Alberto Cambiaghi ${ }^{2}$ and Stefano Cernuschi ${ }^{1}$ \\ ${ }^{1}$ Politecnico di Milano Ringgold standard institution - DICA, p.zza Leonardo Da Vinci 32, Milano, Italy \\ ${ }^{2}$ BEA - Brianza Energia Ambiente SpA, via Gaetana Agnesi 272, Desio, Italy
}

Article Info:

Received:

29 November 2018

Revised:

5 April 2019

Accepted:

29 April 2019

Available online:

24 May 2019

Keywords:

Actual WTE emissions

Traffic emissions

Ambient air quality

Environmental impact assessment

\begin{abstract}
In recent decades there has been an intense debate about the impact of waste-to-energy (WTE) plant emissions on air quality, and therefore on public health. Currently available data from emissions inventories show the negligible impact of waste incineration on air quality. A number of impact assessment studies are currently available too. A few of them are site-specific, but none of them makes a direct comparison between the local impact of the emissions from a WTE plant and emissions from other "common" sources (such as vehicles and domestic heating) perceived as less potentially hazardous in the public opinion. This paper examines the impact on air quality of actual emissions from a WTE plant in the municipality of Desio (located to the North of Milan in the Lombardy region) using CALPUFF atmospheric dispersion model. Continuous emission monitoring data were used to measure the plant's actual emissions of PM10, NOx, cadmium, and dioxins (PCDD/F) as inputs for model simulations. For comparison purposes, the impact of traffic emissions along the main roads in Desio was also simulated. The results of the model show that the WTE plant has a marginal impact on local air quality compared with pollution from vehicular traffic. The contribution of the plant's actual emissions to ambient pollution concentration levels in the urban area of Desio is between two (NOx and cadmium) to four (PM10 and PCDD/F) orders of magnitude smaller than the contribution from road traffic emissions.
\end{abstract}

\section{INTRODUCTION}

Despite ever stricter limits on atmospheric emissions from waste incineration plants and technological improvements in flue gas treatment (Passarini et al., 2014), there is still considerable public concern regarding the potential adverse health effects of waste incineration. Significant positive relationships with broad groups of congenital anomalies in populations living near waste incinerators have been reported in a number of epidemiological studies. However, the results from these studies remain inconclusive due to the limitations of exposure assessment, possible confounding risk factors, and lack of statistical power (Ashworth et al., 2014).

Waste incinerators and state-of-the-art waste-to-energy (WTE) facilities frequently face strong opposition from local communities, making the location of new plants an ongoing concern (Achillas et al., 2011; Ren et al., 2015; Baxter et al., 2016; Song et al., 2017). Health risk assessment studies for new plants are usually based on both maximum plant throughput (i.e. the maximum volume of waste the plant is authorised to burn) and maximum stack concen- trations (i.e. the concentration limit set by regulations for pollutants contained in flue gas emissions). Thus, these studies are based on the maximum mass flow rate of pollutants and provide upper-bound estimates of the impact of the WTE plants on air quality. In practice, plant throughput is typically close to, but still below, the authorised value, while actual pollutant concentrations in flue gas are well below the limit values, sometimes by several orders of magnitude. Given such a prudent approach, health risk assessment studies indicate acceptable incremental risk for the exposed population. Nevertheless, risk perception among the public is biased by a number of factors (Ren et al., 2015), primarily still-low levels of environmental education (i.e. risk awareness and knowledge). Improved communication with regard to risk levels and public engagement (Lidskog and Sundqvist, 2004; Chung and Kim, 2009) may reduce undue risk perception (Petts, 1992). Additionally, informed public opinion of projected benefits and risks, together with increased trust in local government, monitoring bodies and plant operators can further foster public acceptance of potentially hazardous facilities (Mah et al., 2014; Liu et al., 2018). 
Public perception of a plant's impact on air quality can be profitably shaped by studies comparing the contribution of WTE plants to local air pollution with that of other common sources such as traffic, domestic heating or biomass burning, which are publicly perceived as less detrimental to human health yet which may contribute significantly to ambient concentration levels locally. However, such studies are extremely rare in the literature, where comparative studies are usually limited to comparisons of emission inventory data (thus ignoring flue gases released into the atmosphere) or to comparisons with alternative solutions to WTE plants, mostly based on the life-cycle assessment approach (Evangelisti et al., 2015; Dong et al., 2018).

In order to bridge this knowledge gap, this paper takes the WTE plant operated by Brianza Energia Ambiente SpA in the city of Desio (Northern Italy, Lombardy region) as a case study. It has three main aims:

- to assess the plant's impact on local air quality based on actual emission data, in order to examine its impact in more detail and make the findings public knowledge for the benefit of the local population;

- to assess the impact on emissions and local air quality of the most recent plant retrofit, which was carried out in 2016 and involved: i) a 40\% increase in incineration capacity (up to a throughput of about 20 tons per hour); ii) the installation of a new steam turbine; iii) the revamping of the flue gas treatment system, specifically with the installation of a new SCR (selective catalytic removal) unit for NOx emission control;

- to compare the impact of the plant's stack emissions on air quality with that of ground-level road traffic emissions from the main roads in the municipality of Desio. Traffic emissions from minor roads and the general urban road network were not considered.

The study considered two criteria pollutants, PM10 and NOx, concentrations of which are particularly high in Northern Italy and frequently result in current air quality standards being breached, and two toxic pollutants, cadmium (Cd) and dioxins and furans (PCDD/F) typically emitted by waste incineration plants. In order to evaluate the benefits of the 2016 plant retrofit, emission data from the 2015 (prior to the retrofit) and 2017 (following the retrofit) were compared and separately used for air quality model simulations in two different scenarios.

\section{MATERIALS AND METHODS}

\subsection{Study area}

The case study presented in this work is based on the municipality of Desio, a town with a population of 40,000 located in a flat area about 15 kilometres north of Milan in the Lombardy region in Northern Italy. As in most of Northern Italy, air quality is an issue of great concern in Desio, as air quality standards are frequently not respected (Directive 2008/50/EC). As the Lombardy Region's air quality monitoring network has no stations in Desio, the only air quality data available come from regional-scale modelling provided by the Lombardy Regional Environmental Protection Agency (ARPA Lombardia). For 2016, the base year considered in this case study, the annual average concentration estimated for PM10 $\left(31.6 \mu \mathrm{g} / \mathrm{m}^{3}\right)$ was in compliance with the $40 \mu \mathrm{g} / \mathrm{m}^{3}$ EU limit. However, the daily average concentration of PM10 exceeded the $50 \mu \mathrm{g} / \mathrm{m}^{3}$ limit 60 times during the year, on significantly more occasions than the permissible 35 times in a year. The annual average concentration of $\mathrm{NO}_{2}\left(46.4 \mu \mathrm{g} / \mathrm{m}^{3}\right)$ exceeded the $40 \mu \mathrm{g} / \mathrm{m}^{3}$ EU limit, although the hourly average concentration never exceeded the $200 \mu \mathrm{g} / \mathrm{m}^{3}$ concentration limit.

Emission inventory data for Desio (ARPA Lombardia, 2018) are summarised in Table 1 for the pollutants considered in this study, except for PCDD/F, which is not listed in the Lombardy region emission inventory. Among anthropogenic activities, the sector of road transport was the largest source of emissions, accounting for $41.3 \%$ of PM10, $49.9 \%$ of NOx and $24.6 \%$ of $\mathrm{Cd}$ emissions. Non-industrial combustion plants (i.e. commercial and residential heating) were responsible for $24.9 \%$ of PM10 emissions, $9.3 \%$ of NOx emissions and $18.6 \%$ of $\mathrm{Cd}$ emissions. The corresponding shares for the waste treatment and disposal sector were $6.9 \%$ for PM10, 36.8\% for NOx, and $16.8 \%$ for Cd.

\subsection{Air quality model}

The study was conducted using the CALPUFF model (www.src.com), a tri-dimensional air quality model particularly suitable for complex meteorological conditions with light winds and calms, which frequently occur in Northern Italy's Po Valley plain. CALPUFF calculates the time series of 1-hour ground-level concentrations at each grid node of the computational domain. The raw data were then processed by the CALPOST module in order to obtain summary statistical data (e.g. average annual concentration, hourly maximum/daily average/percentile values) for graphical representation through maps showing isoconcentration contour lines. The computational domain was a 10 by 10 kilometre square grid around the WTE plant with 100-metre grid step, giving a total of 10,201 grid points.

Meteorological data were supplied by the Regional Environmental Protection Agency and from the LAMA (Limited Area Meteorological Analysis) database, which was generated using the COSMO meteorological model and GTS data. COSMO is the Italian model for short-term weather

TABLE 1: Emission inventory data for the municipality of Desio (Arpa Lombardia, 2018 - reference year 2014).

\begin{tabular}{l|c|c|c}
\hline Source category & PM10 (t) & Cd (kg) & NOx (t) \\
\hline Non-industrial combustion plants & 7.675 & 0.168 & 31.5 \\
\hdashline Industrial combustion plants & 2.220 & 0.037 & 10.3 \\
\hline $\begin{array}{l}\text { Industrial processes without } \\
\text { combustion }\end{array}$ & 0.245 & 0.003 & 0.0 \\
\hline Use of solvents and other products & 2.910 & 0.004 & 0.0 \\
\hline Road Transport & 12.908 & 0.222 & 168.1 \\
\hdashline $\begin{array}{l}\text { Other mobile sources and ma- } \\
\text { chinery }\end{array}$ & 0.162 & 0.001 & 2.8 \\
\hline Waste treatment and disposal & 2.166 & 0.152 & 124.1 \\
\hline Agriculture & 0.003 & 0.000 & 0.1 \\
\hline Other sources and sinks (nature) & 2.944 & 0.317 & 0.1 \\
\hline
\end{tabular}


forecasts. In order to make it easier to assess the impact of the plant retrofitting operation on air quality, the same meteorological data for 2016 were used for both 2015 and 2017. The ground-level (10-metre height) wind rose for the plant site in the 2016 calendar year is shown in Figure 1. Winds were mostly northerly, blowing from sectors between the North-West and North-East, but also along the EastWest axis. Conversely, southerly winds, coming from the directions between South East and South West, were markedly less frequent.

\subsection{Emission data}

\subsubsection{WTE plant}

A waste incineration plant began operating on the outskirts of the municipality of Desio in 1976. Since then, the plant has been retrofitted several times, most recently in 2016, in order to meet emission standards issued in recent years. Currently, the Desio waste incineration plant is a WTE plant with two combustion lines, each with a maximum power output of $21 \mathrm{MWt}$, and operates according to a Combined Heat and Power (CHP) energy recovery scheme. The two combustion chambers are equipped with moving grates and integrated boilers for a total steam production of $45 \mathrm{t} \mathrm{hr}^{-1}$. Power production relies on a turbine with a maximum power output of $8.25 \mathrm{MW}$. Heat is supplied to a 40-km district heating network, serving Desio and three other municipalities nearby. The maximum thermal power output to the district heating network is $30 \mathrm{MWt}$. The plant is mainly fed with municipal solid waste $(77 \%)$ together with some commercial and industrial waste (16\%), medical waste $(4 \%)$ and sludge (3\%). On average, the lower heating value of the waste is about $12 \mathrm{MJ} \mathrm{t}^{-1}$.
Atmospheric emission control is performed through a flue gas dry treatment line. Dust emissions are controlled by means of an electrostatic precipitator and a baghouse filtration unit. Acidic gases are controlled through a double-alkali injection system (one injection point in the post-combustion chamber and one before the baghouse); dioxins and other organic pollutants are treated by means of activated carbon injection before the baghouse filter. NOx emissions are controlled via a two-stage SNCR/SCR system, with the final SCR system introduced in 2016 retrofit. The plant retrofit did not affect the stack of the plant: treated flue gas is released to the atmosphere through a 47-m tall stack.

For this study, hourly data for flue gas temperature and speed, dust (considered as PM10) and NOx (as $\mathrm{NO}_{2}$ ) concentrations were taken from the continuous emission monitoring (CEM) system database for the 2015 and 2017 calendar years. Thus, model simulations for PM10 and NOx were based on their actual mass flow rates. For $\mathrm{Cd}$ and PCDD/F, which were not continuously monitored, mass flow rates were determined based on the actual flue gas flow rate from CEM data and on fixed concentration data representative of the plant emissions. In particular, concentration data for $\mathrm{Cd}$ were taken from the datasets of the discontinuous sampling performed every year: namely, following a precautionary approach, the highest of the three concentration values available for each year was used $\left(0.193 \mu_{\mathrm{g} \mathrm{m}}^{-3}\right.$ in 2015 and $0.323 \mu \mathrm{g} \mathrm{m}^{-3}$ in 2017, respectively). Concentration data for PCDD/F (as equivalent toxicity - I-TEQ) were taken as the annual sets of 12 monthlyaveraged concentrations derived from the analysis of the integrated samples collected by the PCDD/F continuous sampling system (Table 2). Therefore, the time series of

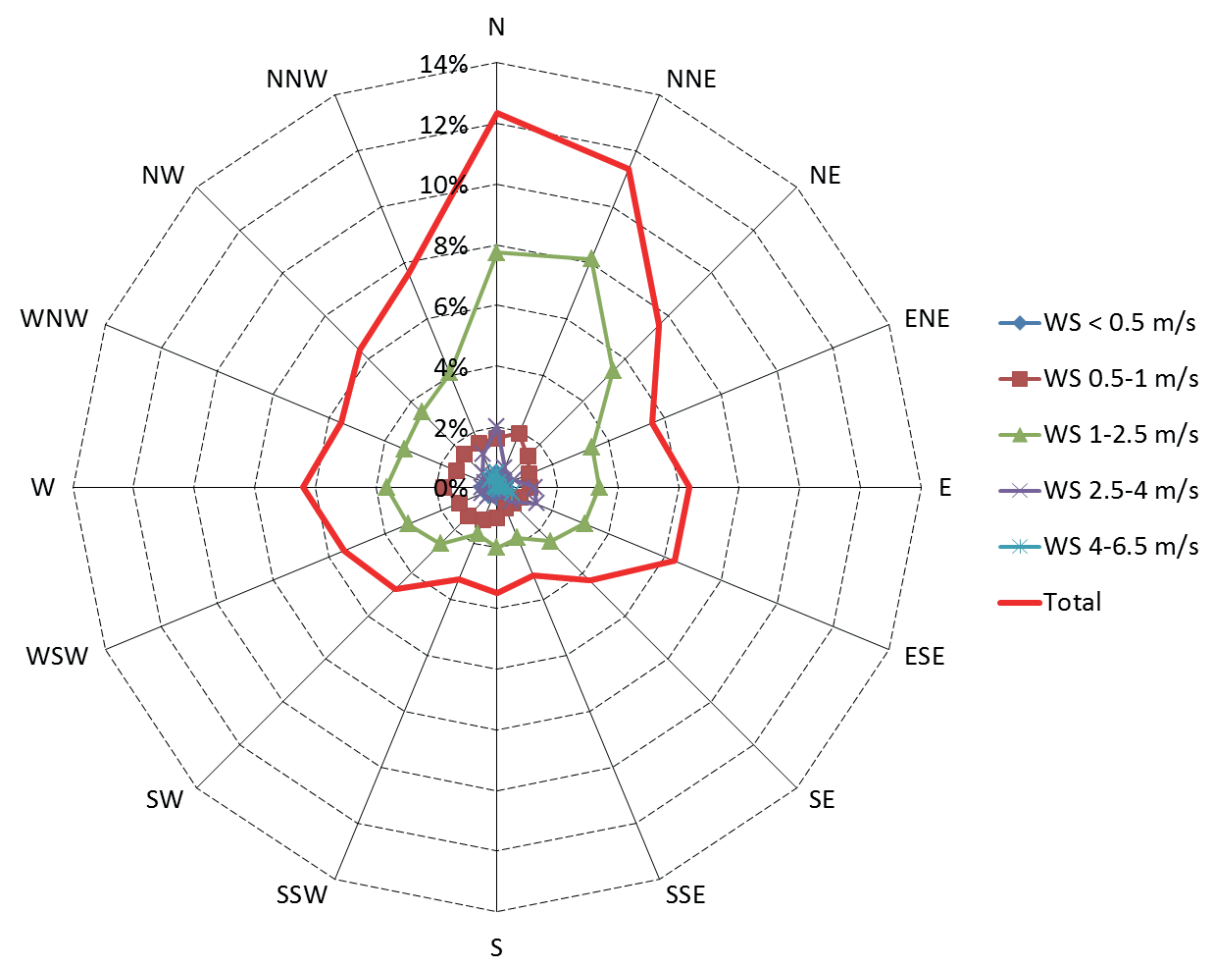

FIGURE 1: Ground-level wind rose for calendar year 2016. 
TABLE 2: Monthly averaged PCDD/F concentration (pgTEQ $\mathrm{m}^{-3}$, normal conditions, dry gas $11 \%$ 02) from PCDD/F continuous sampling system

\begin{tabular}{l|c|c}
\hline Month & Year 2015 & Year 2017 \\
\hline Jan & 1.10 & 0.41 \\
\hline Feb & 0.61 & 0.26 \\
\hline Mar & 0.71 & 0.48 \\
\hline Apr & 1.00 & 0.74 \\
\hline May & 1.06 & 0.76 \\
\hline Jun & 0.43 & 0.04 \\
\hline Jul & 1.25 & 0.71 \\
\hdashline Aug & 0.72 & 0.67 \\
\hdashline Sep & 1.71 & 0.41 \\
\hline Oct & 1.47 & 1.35 \\
\hline Nov & 1.15 & 0.71 \\
\hline Dec & 2.54 & $0.61(*)$ \\
\hline
\end{tabular}

(*) Missing December 2017 data the average concentration of the previous months was used

PCDD/F mass flow rates accounted for both flue gas variability (at hourly resolution) and concentration variability (at monthly resolution).

CEM data for 2017 show that the plant retrofit resulted in both a higher flue gas stack temperature $\left(162^{\circ} \mathrm{C}\right.$ vs. $\left.144^{\circ} \mathrm{C}\right)$ and speed $\left(11.4 \mathrm{~m} \mathrm{~s}^{-1}\right.$ vs. $\left.9.4 \mathrm{~m} \mathrm{~s}^{-1}\right)$ than in 2015 , thus leading to a stronger vertical momentum and buoyancy, both favouring the plume rise and the dispersion of the pollutants into the atmosphere.

In both scenarios pollutant concentrations and mass flow rates were always lower than regulatory limits and authorised mass flow rates (Table 3). PCDD/F and Cd maximum hourly flow rates were well below emission limits (two orders of magnitude lower for PCDD/F and even lower for Cd), five times below emission limits in 2015 and two orders of magnitude lower in 2017 for PM10, 58\% of the authorised flow rate in 2015 and $68 \%$ in 2017 for NOx. However, as NOx and PCDD/F average flow rates were lower in 2017 than in 2015, Cd and PM10 flow rates were higher in 2017 than in 2015.

\subsubsection{Road traffic}

Hourly emissions from traffic on the main roads around the plant were estimated, based on the length of the road segments, on traffic volumes on any segment, and on emis- sion factors for each vehicle type. Traffic flow rates along the road segments were evaluated by means of a dedicated study which assessed hourly traffic volume broken down into three main classes of vehicles (cars, vans and trucks) during a workday rush hour. The study was based on both transport supply system data (i.e. the structure of the road network) and mobility demand data (i.e. an origin-destination trip matrix), together with traffic flow data for the Lombardy region and for the municipality of Desio.

Emission factors were taken from the Lombardy Region Atmospheric Emission Inventory (INEMAR - ARPA Lombardia, 2018), the Italian traffic emissions factors database (ISPRA, 2017) and the EMEP/EEA air pollutant emission inventory guidebook 2016 (EMEP, 2016). Specifically, emission factors for PM10 were taken from the INEMAR inventory, those for $\mathrm{NO}_{2}$ and $\mathrm{Cd}$ from the ISPRA database, and those for PCDD/F from the EEA guidebook. The INEMAR and ISPRA databases directly provide average emission factors for the three vehicle classes: estimates for these values were based data on the composition of the regional and national vehicle fleet, mileage and average speed for urban and extra-urban driving cycles. Emission factors for PCDD/F provided by the EEA Guidebook were combined with data on the vehicle fleet in the Lombardy region in order to estimate average emission factors for the three classes of vehicles considered in this research.

The estimated daily emission pattern was applied for the whole year, without any seasonal or weekly variation. Although this approach may overestimate the contribution of main road traffic, it partially compensates for emissions from traffic on minor and local roads not considered in the calculations. In practice, a comparison between the traffic emission calculations used for this study and the emission inventory data for road traffic in the municipality of Desio in 2014 indicates that the current study underestimates emissions by $30 \%$.

\section{RESULTS AND DISCUSSION}

\subsection{WTE plant contribution}

Isoconcentration maps for the estimated contribution of emissions from the WTE plant to annual average concentrations of $\mathrm{NO}_{2}$ are presented in Figures 2 and 3 for the 2015 and 2017 scenarios, respectively. The spatial distribution of the concentration levels was similar for all pollutants in both years, as the same meteorological data were used as inputs. Differences in concentration levels are due

TABLE 3: Comparison between actual (Scenario 2015 and Scenario 2017) and authorized hourly flow rates of PM10, NOx, Cd, PCDD/F from WTE plant.

\begin{tabular}{|c|c|c|c|c|c|c|c|c|}
\hline \multirow[t]{2}{*}{ Parameter } & \multicolumn{2}{|c|}{$\begin{array}{l}\text { PM10 } \\
\left(\mathrm{g} \mathrm{h}^{-1}\right)\end{array}$} & \multicolumn{2}{|c|}{$\begin{array}{c}\text { NOx } \\
\left(\mathbf{k g ~ h}^{-1}\right)\end{array}$} & \multicolumn{2}{|c|}{$\begin{array}{c}C d \\
\left(\mathrm{mg} \mathrm{h}^{-1}\right)\end{array}$} & \multicolumn{2}{|c|}{$\begin{array}{c}\text { PCDD/F } \\
\left(\mathrm{ng}_{\mathrm{TEQ}} \mathbf{h}^{-1}\right)\end{array}$} \\
\hline & 2015 & 2017 & 2015 & 2017 & 2015 & 2017 & 2015 & 2017 \\
\hline Average & 15.5 & 20.9 & 7.38 & 4.00 & 11.4 & 22.2 & 69.1 & 39.9 \\
\hline Median & 10.8 & 21.6 & 7.38 & 4.00 & 11.6 & 23.3 & 64.8 & 40.7 \\
\hline Minimum & 0.4 & 1.4 & 0.07 & 0.22 & 0.6 & 4.5 & 3.2 & 1.8 \\
\hline Maximum & 205.6 & 72.7 & 12.82 & 14.54 & 15.4 & 29.4 & 202.7 & 110.2 \\
\hline Max Authorized & \multicolumn{2}{|c|}{1,100} & \multicolumn{2}{|c|}{22} & \multicolumn{2}{|c|}{5,500} & \multicolumn{2}{|c|}{11,000} \\
\hline
\end{tabular}




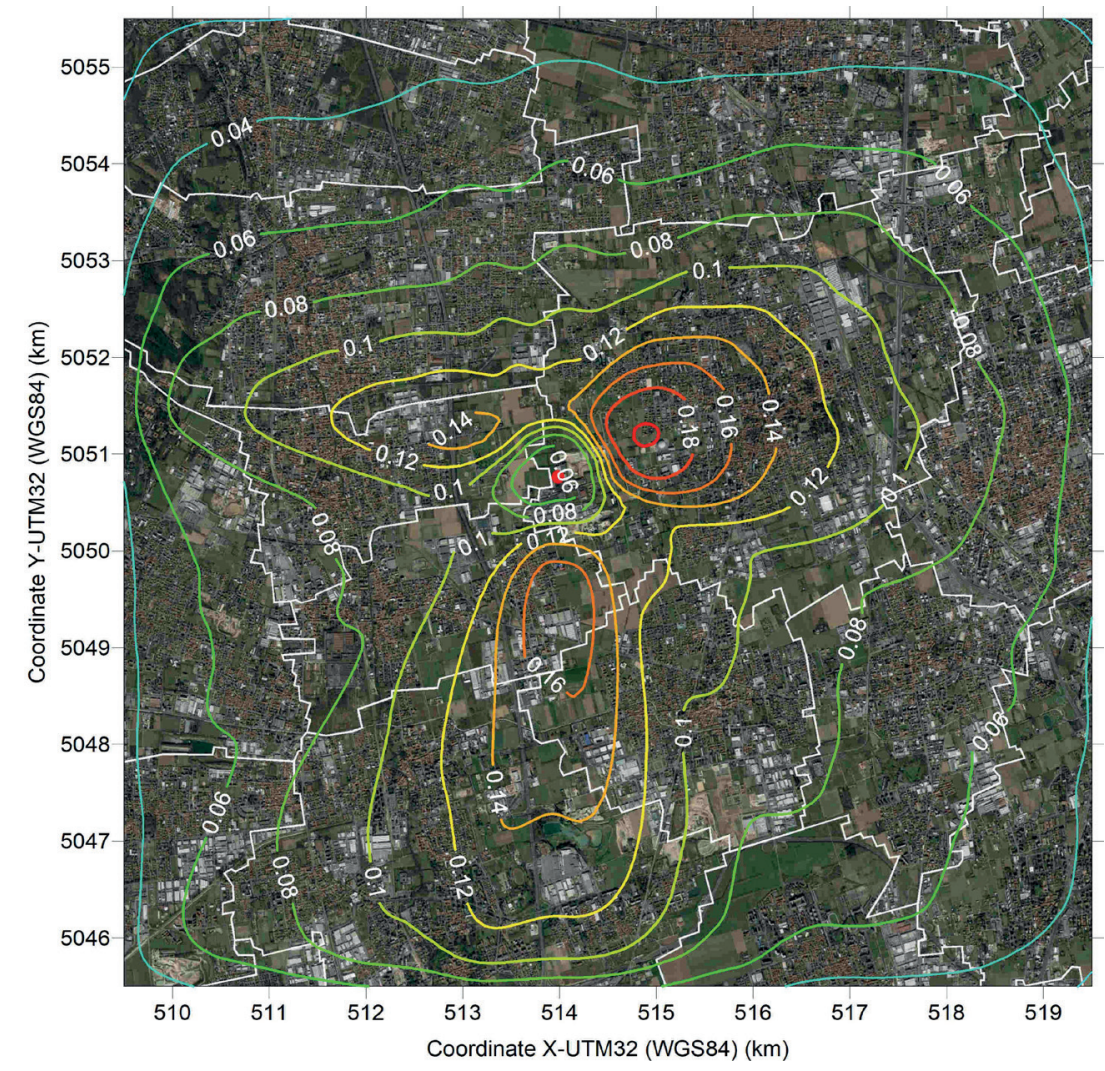

FIGURE 2: Emission scenario 2015: contribution of WTE plant emissions to $\mathrm{NO}_{2}$ annual average concentration $\left(\mu \mathrm{g} \mathrm{m}^{-3}\right)$ before of plant retrofit. (red dot: WTE plant; white lines: municipality borders; aerial map source: Google Earth).

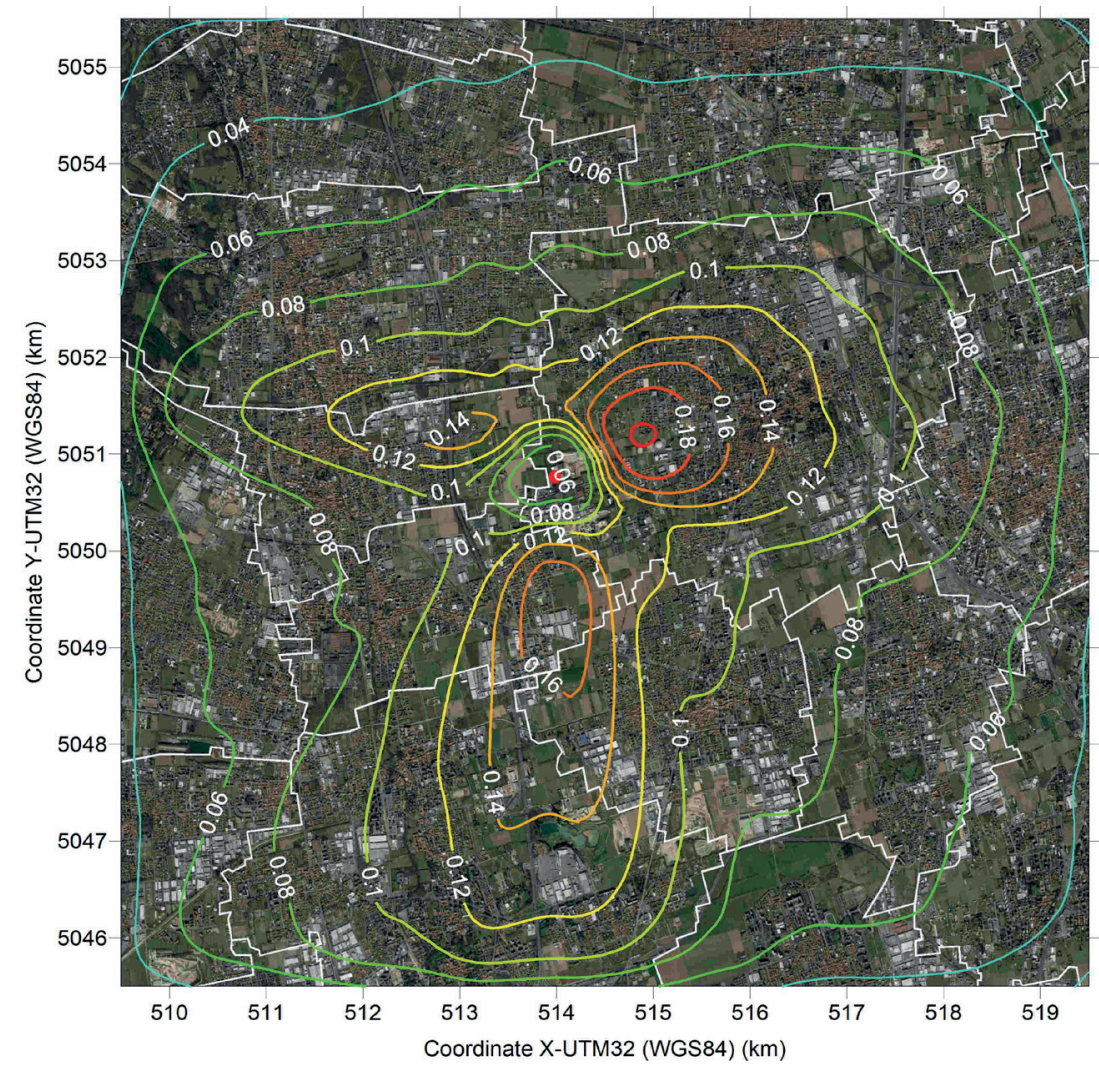

FIGURE 3: Emission scenario 2017: contribution of WTE plant emissions to $\mathrm{NO}_{2}$ annual average concentration $\left(\mu \mathrm{g} \mathrm{m}^{-3}\right)$ after plant retrofit. (red dot: WTE plant; white lines: municipality borders; aerial map source: Google Earth). 
to the emissions rate only. The distribution pattern shows three lobes, extending North-West, North-East and South of the plant, according to the most frequent wind directions in the area. The area with the highest impact (i.e. where the maximum contribution is estimated) is located about 1 kilometre North-East of the plant, on the outskirts of the Desio urban area. However, emissions from the plant also affect air quality in the centre of the town. Table 4 summarises the values at the maximum fallout point and the annual average concentration of pollutants at ground level within the residential area of Desio before and after the WTE plant retrofit (i.e. the scenarios for 2015 and 2017). The table also compares emissions with air quality regulatory limits (EU Directive 2008/50). Plant emissions were found to have an extremely limited impact on air quality, both before and after retrofitting. After the retrofit, plant emissions accounted for $0.001 \%$ of the acceptable limit for PM $10,0.2 \%$ of $\mathrm{NO}_{2}, 0.05 \%$ of $\mathrm{Cd}$ and $0.0005 \%$ of PCDD/F as set out in German regulations (LAl, 2004). The impact of emissions from the WTE plant were also negligible as far as regulatory short-term concentrations for $\mathrm{PM} 10$ and $\mathrm{NO}_{2}$ are concerned.

\subsection{Traffic contribution}

An isoconcentration map for the estimated contribution of road traffic to the annual average concentration of $\mathrm{NO}_{2}$ is presented in Figure 4. As traffic was modelled considering the main roads only and due to its ground-level emission, the resulting spatial distribution has a less regular pattern than the one obtained for the WTE plant and is essentially driven by the layout of the road network under consideration. Maximum pollutant concentrations occurred in proximity to the road axes and decreased sharply with distance from them. In particular, the impact of emissions from the major roads 35 and 36 are clearly visible with their NorthSouth alignment on the left and the right side of the map, bordering the municipality of Desio.

The highest annual average values were in the order of 5-6 $\mathrm{mg} \mathrm{m}^{-3}$ for PM10, 15-20 $\mu \mathrm{g} \mathrm{m}^{-3}$ for $\mathrm{NO}_{2}, 0.08-0.1 \mathrm{ng}$ $\mathrm{m}^{-3}$ for $\mathrm{Cd}$, and 2-3 $\mathrm{fg}_{\mathrm{TEQ}} \mathrm{m}^{-3}$ for PCDD/F. For the residential area of Desio, away from the main roads, the model results show concentration levels ranging between $2-3 \mu^{-3} \mathrm{~m}^{-3}$ for PM10, 6-10 $\mathrm{g} \mathrm{m} \mathrm{m}^{-3}$ for $\mathrm{NO}_{2}, 0.02-0.03 \mathrm{ng} \mathrm{m}^{-3}$ for $\mathrm{Cd}$, and between 0.5-1 fg $\mathrm{fEQ}_{\mathrm{TEQ}} \mathrm{m}^{-3}$ for PCDD/F (Table 5). The highest short-term concentrations were in the $3-6 \mu \mathrm{g} \mathrm{m}^{-3}$ range for 24-hour PM10 and in the $100-150 \mu \mathrm{g} \mathrm{m}^{-3}$ range for 1 -hour $\mathrm{NO}_{2}$, roughly $10 \%$ and $50-70 \%$ of the corresponding air quality limits (50 $\mathrm{g} \mathrm{m} \mathrm{m}^{-3}$ for PM10, $200 \mu \mathrm{g} \mathrm{m}^{-3}$ for $\mathrm{NO}_{2}$ ).

\subsection{Comparison between source contributions}

A comparison between the estimated annual average concentrations due to the emissions from the WTE plant and from traffic on the main roads crossing Desio municipality shows the much higher role of traffic on local-scale air pollution. This is true both for the contribution estimated at the point of maximum fallout and within the residential area of Desio. The contribution from traffic to any of the pollutants under consideration is at least two orders of magnitude higher than the contribution from the WTE plant in the residential area of Desio (Table 5). Contributions from traffic to PM10 concentrations are four orders of magnitude (10,000 times) higher than those from the WTE plant. For PCDD/F concentrations the corresponding figure is three orders of magnitude (1,000 times) higher, while for $\mathrm{NO}_{2}$ and $\mathrm{Cd}$ concentrations it is two orders of magnitude (100 times) higher. For short-term concentrations, similarly, the impact of traffic is far higher than the impact of the WTE plant in the residential area of Desio: the contribution of traffic to PM10 and $\mathrm{NO}_{2}$ emissions is about 1,000 times and 40-50 times higher, respectively, than from the WTE plant. Similar considerations hold for the point where the maximum fallout from the WTE plant is expected, although this is located at a considerable distance from the main roads and is thus affected less by traffic emissions.

The results of the study show that road traffic is responsible for about $20 \%$ of annual average $\mathrm{NO}_{2}$ concentrations and $10 \%$ of annual average PM10 concentrations in Desio. For Cd levels, an assessment of the role of road traffic emissions cannot rely on specific values for Desio because of the lack of an air quality monitoring station; additionally, regional-scale modelling data provided by ARPA Lombardia do not include $\mathrm{Cd}$. However, annual average $\mathrm{Cd}$ data from monitoring stations in Milan in 2017 were in the 0.27-0.33 $\mathrm{ng} \mathrm{m}^{-3}$ range. Thus we may reasonably assume that road traffic is responsible for roughly $10 \%$ of the annual average concentration of $\mathrm{Cd}$, in line with its estimated contribution to PM10 levels.

Putting the plant's estimated contributions to PCDD/F air pollution levels in context is harder as this pollutant is not considered by air quality standards and thus not rou-

TABLE 4: Annual average concentration at the maximum fallout point, concentration range within the residential area of Desio and air quality limits for PM10, $\mathrm{NO}_{2}$, Cd (EU Directive 2008/50/EC) and PCDD/F (German guidelines on air quality: LAI-Laenderausschuss fur Immissiosschutz).

\begin{tabular}{|c|c|c|c|c|c|}
\hline Scenario & Parameter & $\begin{array}{c}\text { PM10 } \\
\left(\mu \mathrm{g} \mathrm{m}^{-3}\right)\end{array}$ & $\begin{array}{c}\mathrm{NO}_{2} \\
\left(\mu \mathrm{g} \mathrm{m}^{-3}\right)\end{array}$ & $\begin{array}{c}\mathrm{Cd} \\
\left(\mathrm{ng} \mathrm{m}^{-3}\right)\end{array}$ & $\begin{array}{c}\mathrm{PCDD} / \mathrm{F} \\
\left(\mathrm{fg}_{\mathrm{TEQ}} \mathrm{m}^{-3}\right)\end{array}$ \\
\hline \multirow[t]{2}{*}{2015} & Maximum value & $5.2 \cdot 10^{-4}$ & 0.20 & $3.3 \cdot 10^{-4}$ & $2.3 \cdot 10^{-3}$ \\
\hline & $\begin{array}{l}\text { Desio residential } \\
\text { area (range) }\end{array}$ & $3-4.5 \cdot 10^{-4}$ & $0.12-0.18$ & $2-3 \cdot 10^{-4}$ & $1.2-1.8 \cdot 10^{-3}$ \\
\hline \multirow[t]{2}{*}{2017} & Maximum value & $4.4 \cdot 10^{-4}$ & 0.08 & $4.8 \cdot 10^{-4}$ & $8.1 \cdot 10^{-4}$ \\
\hline & $\begin{array}{l}\text { Desio residential } \\
\text { area (range) }\end{array}$ & $2-3.5 \cdot 10^{-4}$ & $0.05-0.07$ & $3-4 \cdot 10^{-4}$ & $5-7 \cdot 10^{-4}$ \\
\hline \multicolumn{2}{|c|}{$\begin{array}{c}\text { Air quality limits } \\
\text { (annual average value) }\end{array}$} & 40 & 40 & 1 & 150 \\
\hline
\end{tabular}




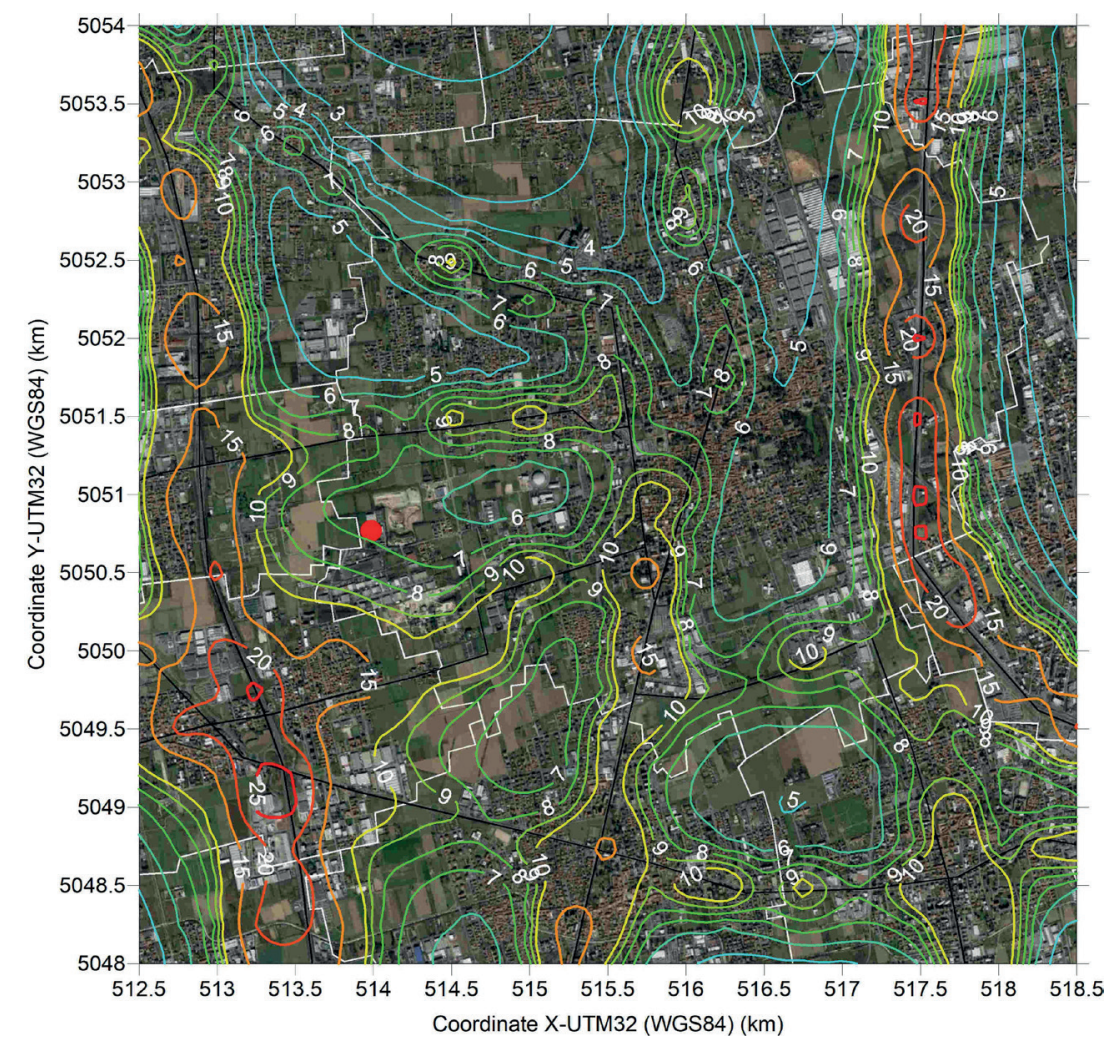

FIGURE 4: Contribution of road traffic emissions to NO2 annual average concentration $\left(\mu \mathrm{g} \mathrm{m}^{-3}\right)$. (red dot: WTE plant; black lines: main roads considered in this study; white lines: municipality borders; aerial map source: Google Earth).

tinely monitored. Additionally, monitoring campaigns for PCDD/F usually have a limited time-span and do not provide annual average values. Values for PCDD/F concentrations in urban areas vary significantly in the literature, ranging from a few dozen (Turrio-Baldassarri et al., 2005; Schlabach and Tønnessen, 2008) to several hundred $\mathrm{fg}_{\mathrm{TEQ}}$ $\mathrm{m}^{-3}$ (Li et al., 2008). The WHO has estimated average levels of $100 \mathrm{fg}_{\text {TEQ }} \mathrm{m}^{-3}$ for the urban environment (WHO, 2000). Studies developed in Northern Italy report PCDD/F values in the order of $5-100 \mathrm{fg}_{\text {TEQ }} \mathrm{m}^{-3}$ (ARPA Veneto, 2016). Such variability is strongly correlated with local factors, mainly related to the presence of industrial plants and the practice of wood burning for household heating. PCDD/F levels in ambient air in proximity to state-of-the-art waste incinerators in Northern Italy have been found to be in the range of $10-125 \mathrm{fg}_{\text {I-TEQ }} \mathrm{m}^{-3}$ and between 144 and $337 \mathrm{fg}_{\text {I-TEQ }} \mathrm{m}^{-3}$ in proximity to an old plant not equipped with the best available technology (BAT) for the removal of dioxins (Caserini et al., 2004); a more recent study after this plant was retrofitted with BAT reported maximum levels of about 25 $\mathrm{fg}_{\text {I-TEQ }} \mathrm{m}^{-3}$ as a weekly average for the winter period (ARPA Veneto, 2018). Given this remarkably wide range of values, we can assume that the actual contribution may range from a few percentage points up to $20 \%$ of the annual average concentration.

However, all these percentage contributions underestimate the true impact of traffic emissions, as this study only considered the main roads while ignoring the contribution of traffic on the urban minor road network. Taking this latter contribution into account, we may estimate that road traffic is responsible for about $15 \%$ of annual average PM10 and Cd concentrations and $30 \%$ of $\mathrm{NO}_{2}$ concentrations.

\section{CONCLUSIONS}

The results of the model provide evidence of the positive effects of the flue gas treatment retrofit in the Desio WTE plant on $\mathrm{NO}_{x}$ and PCDD/F, emissions of which have been halved. Additionally, the higher temperature and velocity of the effluents following the retrofit have increased the dispersion of pollutants, reducing average annual pollutant concentrations by $60 \%$. Thus the impact on air quality has been reduced, in spite of increased incineration

TABLE 5: Range of estimated contributions from WTE plant and road traffic emissions to the annual average concentrations of $\mathrm{PM} 10, \mathrm{NO}_{2}$, $\mathrm{Cd}, \mathrm{PCDD} / \mathrm{F}$ in the residential area of Desio.

\begin{tabular}{|c|c|c|c|c|}
\hline Source & $\begin{array}{c}\text { PM10 } \\
\left(\mu \mathrm{g} \mathrm{m}^{-3}\right)\end{array}$ & $\begin{array}{c}\mathrm{NO}_{2} \\
\left(\mu \mathrm{g} \mathrm{m}^{-3}\right)\end{array}$ & $\begin{array}{c}\text { Cd } \\
\left(\mathrm{ng} \mathrm{m}^{-3}\right)\end{array}$ & $\begin{array}{c}\mathrm{PCDD} / \mathrm{F} \\
\left(\mathrm{fg}_{\mathrm{TEQ}} \mathrm{m}^{-3}\right)\end{array}$ \\
\hline WTE plant (Scenario 2017) & $0.0002-0.00035$ & $0.05-0.07$ & $0.0003-0.0004$ & $0.0005-0.0007$ \\
\hline Road traffic & $2-3$ & $6-10$ & $0.02-0.03$ & $0.5-1$ \\
\hline
\end{tabular}


capacity. Generally speaking, WTE plant emissions have a very low impact on local air quality, both in terms of annual and hourly averaged concentrations and for the main pollutants such as PM10 and $\mathrm{NO}_{2}$ and for organic micro-contaminants and persistent inorganic toxic pollutants such as dioxins and cadmium.

The extremely low impact of WTE emissions is highlighted by the comparison with the estimated impact of the traffic in the same area, which is likely to be underestimated as the study considers main roads only while ignoring the dispersed, low-speed/high-emission factor, stop-andgo traffic on the network of minor roads. On average, the contribution of traffic in the residential area of Desio is between two and four orders of magnitude higher than the WTE plant impact, both for criteria and toxic pollutants. Considering average annual values, the contribution from traffic is four orders of magnitude higher than that of the WTE plant for PM10, three orders of magnitude higher for dioxins, and two orders of magnitude higher for $\mathrm{NO}_{2}$ and cadmium. The impact of traffic is even higher when shortterm concentration values for $\mathrm{PM} 10$ and for $\mathrm{NO}_{2}$ are considered.

\section{ACKNOWLEDGEMENTS}

The research described in this paper was entirely funded by BEA Spa under a research contract with the Civil and Environmental Department (DICA) of the Politecnico di Milano.

\section{REFERENCES}

Achillas, C., Vlachokostas, C., Moussiopoulos, N., Banias, G., Kafetzopoulos, G., Karagiannidis, A., 2011. Social acceptance for the development of a waste-toenergy plant in an urban area. Resour. Conserv. Recy. 55, 857-863

ARPA Lombardia (2018) INEMAR, Inventario Emissioni in Atmosfera: emissioni in Regione Lombardia nell'anno 2014 - revisione pubblica.

http://www.inemar.eu/xwiki/bin/view/InemarDatiWeb/Inventario+dell e+emissioni+in+atmosfera (accessed November 2017)

ARPA Veneto, 2016. Progetto Acciaierie Monitoraggio della qualità dell'aria presso Altavilla Vicentina, Vicenza Ferrovieri e Vicenza quartiere Italia - ARPAV DAP VI 2017.

ARPA Veneto, 2018. Studio e determinazione delle ricadute dell'impianto di termovalorizzazione di Schio.

Ashworth, D.C., Elliott, P., Toledano, M.B., 2014. Waste incineration and adverse birth and neonatal outcomes: a systematic review, Environ. Int. 69, 120-132. doi: 10.1016/j.envint.2014.04.003

Baxter, J., Ho, Y., Rollins, Y., Maclaren, V., 2016. Attitudes toward waste to energy facilities and impacts on diversion in Ontario, Canada. Waste Manage. 50, 75-85

Caserini, S., Cernuschi, S. Giugliano, M., Grosso, M., Lonati, G., Mattaini, P., 2004. Air and soil dioxin levels at three sites in Italy in proximity to MSW incineration plants. Chemosphere 54, 1279-1287.

Chung, J.B., Kim, H.K., 2009. Competition, economic benefits, trust, and risk perception in siting a potentially hazardous facility. Landscape Urban Plan. 91, 8-16
Dong, J. Tang, Y., Nzihou, A., Chi, Y., Weiss-Hortala, E., Ni, M., Zhou, Z., 2018. Comparison of waste-to-energy technologies of gasification and incineration using life cycle assessment: Case studies in Finland, France and China. J. Clean. Prod. 203, 287-300

EMEP/EEA 2016. EMEP/EEA air pollutant emission inventory guidebook. https://www.eea.europa.eu/themes/air/emep-eea-air-pollutant-emission-inventory-guidebook (accessed November 2017)

European Union, 2008. Directive 2008/50/EC of the European Parliament and of the Council of 21 May 2008 on ambient air quality and cleaner air for Europe, OJ L 152, 11.6.2008, 1-44

Evangelisti, S., Tagliaferri, C., Clift, R., Lettieri, P., Taylor, R., Chapman, C., 2015. Life cycle assessment of conventional and two-stage advanced energy-from-waste technologies for municipal solid waste treatment. J. Clean. Prod. 100, 212-223

ISPRA 2017 - La banca dati dei fattori di emissione medi del trasporto stradale in Italia. http://www.sinanet.isprambiente.it/it/sia-ispra/ fetransp/ (accessed November 2017)

LAI (Länderausschuss für Immissionsschutz), 2004. Bericht des Länderausschusses für Immissionsschutz (LAl) Bewertung von Schadstoffen, für die keine Immissionswerte festgelegt sind Orientierungswerte für die Sonderfallprüfung und für die Anlagenüberwachung sowie Zielwerte für die langfristige Luftreinhalteplanung unter besonderer Berücksichtigung der Beurteilung krebserzeugender Luftschadstoffe.

https://www.lanuv.nrw.de/fileadmin/lanuv/gesundheit/pdf/LAI2004. pdf (accessed November 2017)

Li, Y., Jiang, G., Wang, Y., Cai, Z., Zhang, Q. 2008. Concentrations, profiles and gas-particle partitioning of polychlorinated dibenzo-p-dioxins and dibenzofurans in the ambient air of Beijing, China. Atmos. Environ. 42, 2037-2047.

Lidskog, R., Sundqvist, G., 2004. On the right track? Technology, geology and society in Swedish nuclear waste management. J. Risk Res. 7, 251-268

Liu, Y., Sun, C. Xia, B. Cui, C., Coffey, V., 2018. Impact of community engagement on public acceptance towards waste-to-energy incineration projects: empirical evidence from China. Waste Manag. 76, 431-442. doi: 10.1016/j.wasman.2018.02.028

Mah, D.N.-Y., Hills, P., Tao, J., 2014. Risk perception, trust and public engagement in nuclear decision-making in Hong Kong. Energ. Policy 73, 368-390

Passarini, F., Nicoletti, M., Ciacci, L., Vassura, I., Morselli, L., 2014. Environmental impact assessment of a WTE plant after structural upgrade measures. Waste Manag. 34, 753-762. doi: 10.1016/j. wasman.2013.12.022

Petts, J., 1992. Incineration risk perceptions and public concern: experience in the U.K. improving risk communication. Waste Manage. Res. 10, 169-182. doi: 10.1177/0734242X9201000205

Ren, X., Che, Y., Yang, K., Tao, Y., 2015. Risk perception and public acceptance toward a highly protested Waste-to-Energy facility. Waste Manag. 48, 528-539. doi: 10.1016/j.wasman.2015.10.036

Schlabach, M., Tønnessen, D. 2008. Urban Background Levels of Dioxin and PCB in Oslo. NILU (Norwegian Institute for Air Research) Report 2453/2008, ISBN 978-82-7655-552-3.

Song, J., Sun, Y., Jin, L., 2017. PESTEL analysis of the development of the waste-to-energy incineration industry in China. Renew. Sust. Energ. Rev. 80, 276-289.

Turrio-Baldassarri, L., Abate, V., lacovella, N., Monfredini, F., Menichini, E. 2005. Occurrence of PCDD/Fs in urban air before and after the ban of leaded gasoline. Chemosphere, 59, 1517-1524

WHO (World Health Organization), 2000. Air Quality Guidelines for Europe-Second Edition. WHO Regional Publications, European Series, No. 91 